\title{
Porcelain crabs (Crustacea: Decapoda: Anomura) of western coast of India
}

\author{
Imtiyaz Beleem ${ }^{1}$, Paresh Poriya ${ }^{2}$ and Bharatsinh Gohil ${ }^{1 *}$
}

\begin{abstract}
Background: Significant works have been done on the diversity and distribution of porcellanids crabs in Indian coasts. The present work reports and describe porcelain crabs from the western coast of India.

Result: Five species of porcelain crabs in three genera are reported from the western coast of India. Morphological descriptions with measurement of the reported species with key characters and distribution status are given.

Conclusion: Petrolisthes boscii (Audouin, 1826), P. lamarckii (Leach, 1820), and P. rufescens (Heller, 1861) are commonly distributed along the studied coast. Enosteoides ornatus (Stimpson, 1858) and Pachycheles tomentosus (Henderson, 1893) sparsely occur and are firstly reported from the Gujarat coast.
\end{abstract}

Keywords: Crustacea, Porcelain crabs, Distribution, New records, West coast, India

\section{Background}

The anomuran crustacean family Porcellanidae (porcelain crabs or false crabs) can be easily distinguished from brachyura (true crabs) by having the fifth pereopod which is reduced in size and often hidden beneath the carapace, the antennae with an elongate flagellum and the abdomen which does not fit closely to the underside of the cephalothorax (Poore and Ahyong 2004; Osawa and Chan, 2010). The family includes approximately 280 species in 30 genera from tropical to temperate waters of the world (e.g., Osawa and McLaughlin, 2010; Osawa and Uyeno, 2013; Dolorosa and Werding, 2014). Porcelain crabs are mainly inhabitants of intertidal coasts, found beneath humid rocks, dead corals and in muddy bottoms (Werding and Hiller, 2004), while, in sub-tidal region, they occasionally live in association with other invertebrates such as sea urchin, soft corals, worm tubes, sponges and hydrozoans (Werding, 1983; Hiller et al. 2004; Hiller et al. 2006; Osawa and Chan, 2010). These crabs are also well known for their escape tactics in response to the potential predators by voluntary shedding of limbs (Wasson et al. 2002). Significant works have been done on the diversity and distribution of porcellanids in Indian coasts (e.g. Heller 1862, 1865; Henderson

\footnotetext{
* Correspondence: bharatsinhmgohil@gmail.com

${ }^{1}$ Department of Life Sciences, Maharaja Krishnakumarsinhji Bhavnagar

University, Bhavnagar 364002, India

Full list of author information is available at the end of the article
}

1893; Southwell 1906; Gravely 1927; Sankarankutty 1961a, b, 1963; Sankolli 1966; Mustaquim 1972; Ahmed and Mustaquim 1974; Poupin et al. 2013; Prakash et al. 2013a). Recently, Prakash et al. (2013b) provided an updated checklist of porcellanids with their distribution and ecology in Indian waters, including 30 species in 11 genera. Kumaralingam et al. (2015) subsequently reported one more species Neopetrolisthes spinatus Osawa and Fujita, 2001 from the Andaman Islands as new to the Indian fauna. Additionally, porcelain crabs in the western Indian coast have been also studied by Southwell (1909); Siddiqui and Kazmi (2003); Kazmi and Siddiqui (2006); Hiller et al. (2010); Trivedi and Vachhrajani (2013) and Beleem et al. (2014). In this short report, we report five porcellanid species from Gujarat in the western coast of India. Among them, Enosteoides ornatus (Stimpson, 1858) and Pachycheles tomentosus (Henderson, 1893) are first records for this region.

\section{Methods}

Gujarat is situated on the western extreme of Indian subcontinent. The coastline of Gujarat is generally divided into the Gulf of Kutch, Saurahstra coast and the Gulf of Khambhat. In the present study, intertidal zones of eight different locations on Gujarat coast were surveyed for the diversity of porcellanid fauna (Fig. 1). These locations are Diu $\left(20^{\circ} 42^{\prime} 11.52^{\prime \prime} \mathrm{N}, 70^{\circ} 58^{\prime} 34.30^{\prime \prime} \mathrm{E}\right)$, Veraval $\left(20^{\circ} 54^{\prime} 48.33^{\prime \prime} \mathrm{N}, 70^{\circ} 20^{\prime} 55.48^{\prime \prime} \mathrm{E}\right)$, Chorwad $\left(21^{\circ}\right.$ 


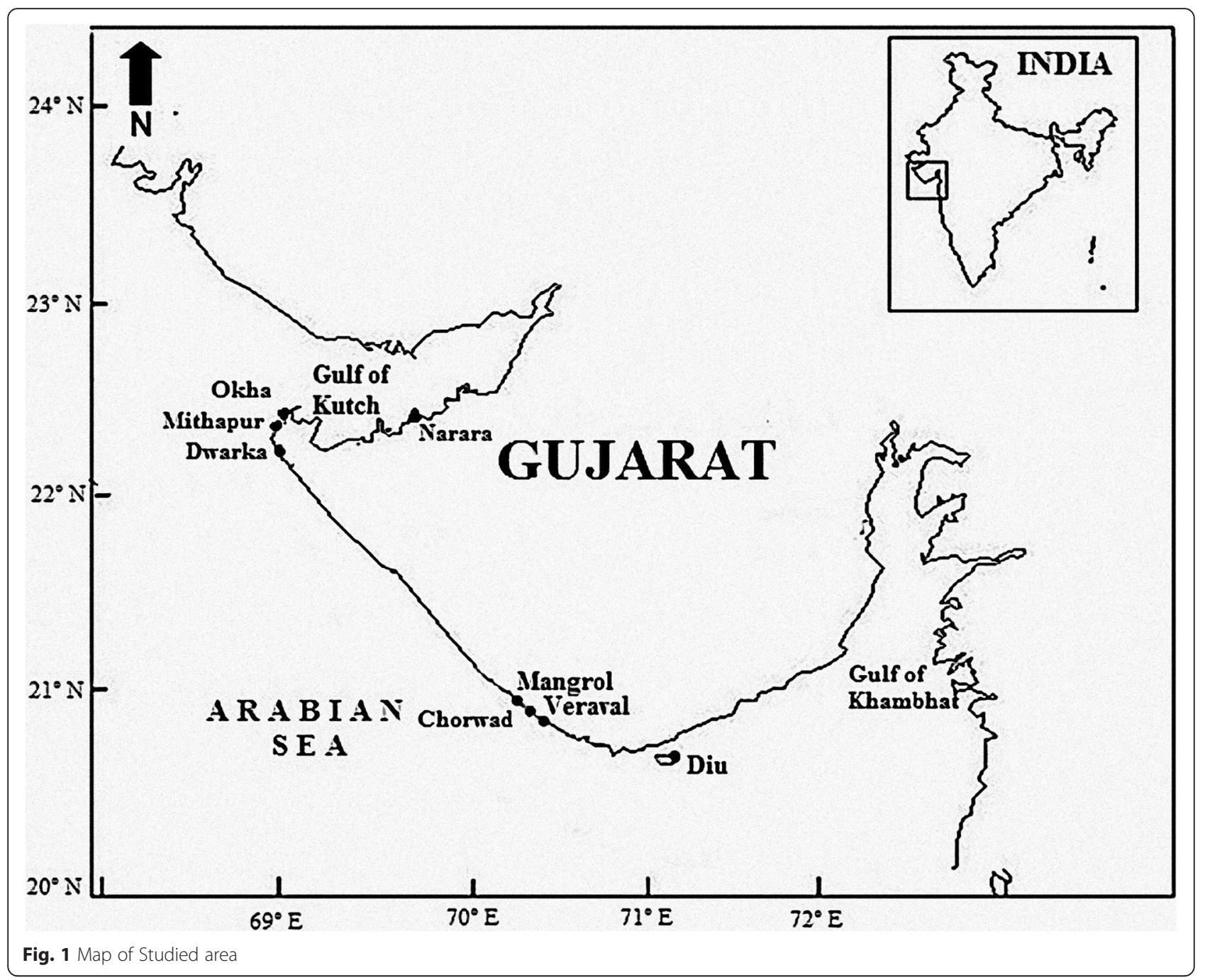

0'5.65"N, 70¹3'28.94"E), Mangrol (216'54.14"N, 70

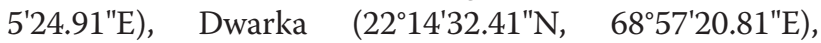
Mithapur $\left(22^{\circ} 25^{\prime} 11.86^{\prime \prime} \mathrm{N}, 68^{\circ} 59^{\prime} 28.52^{\prime \prime} \mathrm{E}\right)$, Okha $\left(22^{\circ}\right.$ $\left.28^{\prime} 42.60^{\prime \prime} \mathrm{N}, 69^{\circ} 4^{\prime} 7.55^{\prime \prime} \mathrm{E}\right)$ and Narara $\left(22^{\circ} 28^{\prime} 22.20^{\prime \prime} \mathrm{N}, 69^{\circ}\right.$ $\left.43^{\prime} 21.90^{\prime \prime E}\right)$. Crabs were handpicked and preserved in $10 \%$ formalin. Collected specimens were brought to the laboratory and identified using the identification keys of Henderson (1893); Osawa (2007); Werding and Hiller (2007) and Hiller et al. (2010). Standard vernier callipers and stereo zoom microscope (Carl Zeiss Primo Star) were used to measure the morphometric of specimens. Synonymy of five species treated in this study follows that of Osawa and McLaughlin (2010).

\section{Results and discussions}

Five species belonging to three genera were identified and their location sites are shown in Table 1. Three species were previously reported from Saurashtra and Kutch coasts. Other two species are firstly recorded from Gujarat coastline.

\section{Systematics}

Order DECAPODA Latreille, 1802

Infraorder ANOMURA MacLeay, 1838

Table 1 Occurrence of porcelain crabs along Gujarat coast, India

\begin{tabular}{llllllllll}
\hline No. & Scientific name & 1 & 2 & 3 & 4 & 5 & 6 & 7 & 8 \\
\hline 1 & Enosteoides ornatus & - & - & - & - & - & + & - & + \\
2 & Pachycheles tomentosus & - & + & - & - & - & - & - & - \\
3 & Petrolisthes boscii & + & + & + & - & - & + & + & + \\
4 & Petrolisthes lamarckii & + & + & - & + & + & + & + & + \\
5 & Petrolisthes rufescens & - & - & - & - & - & + & + & + \\
\hline
\end{tabular}

(First row indicates places: 1-Diu, 2-Veraval, 3-Chorwad, 4-Mangarol, 5-Dwarka, 6-Mithapur, 7-Okha, and 8-Narara) 
Family PORCELLANIDAE Haworth, 1825

\section{Genus Enosteoides Johnson, 1970}

1. Enosteoides ornatus (Stimpson, 1858) (Fig. 2a)

\section{Synonymy}

Porcellana ornata Stimpson, 1858; Porcellana corallicola Haswell, 1882.

\section{Material examined}

2ㅇ, (1) CL: $6.0 \mathrm{~mm}, \mathrm{CW}: 5.6 \mathrm{~mm}$; (2) CL: $5.3 \mathrm{~mm}$, CW: $4.8 \mathrm{~mm}$.

\section{Description}

Carapace as long as broad, front with indistinct lateral lobes and distinct groove on dorsal midline, epibranchial margin unevenly convex, dorsal surface uneven, regions well marked. Chelipeds nearly identical in shape and armature, flattish; merus denticulate with rounded projection at antero-distal edge; carpus denticulate on dorso-anterior margin, dorsal surface with three longitudinal crests, posterior margin with sharp spine at distal end; palm with two rows of tubercles on dorsal surface, anterior margin covered with feathery setae. Ambulatory legs covered with feathery setae; merus unarmed; carpus with one spine at postero-distal end; propodus with one spine at distal end on posterior margin; dactylus with five movable spines on posterior margin.

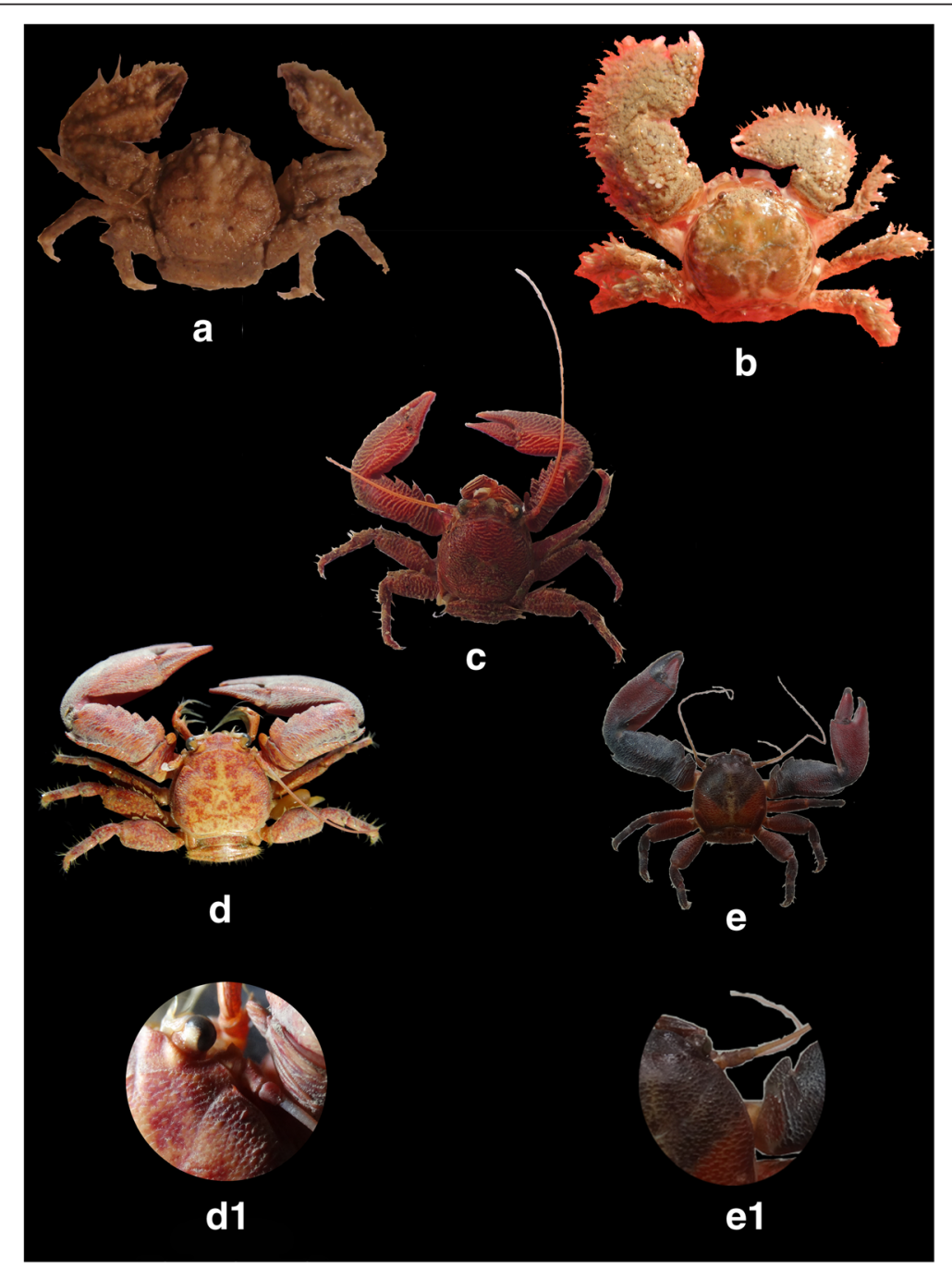

Fig. 2 Entire animal dorsal view (a) Enosteoides ornatus, female, CL: 06 mm, CW: 5.6 mm. b Pachycheles tomentosus, male, CL: 8.2 mm, CW: 7.5 mm. c Petrolisthes boscii, male, CL: $7.1 \mathrm{~mm}, \mathrm{CW}: 6.9 \mathrm{~mm}$ (d) Petrolisthes lamarckii, ovigerous female, CL: $18.3 \mathrm{~mm}, \mathrm{CW}: 15.2 \mathrm{~mm}$ (d1) same, carapace branchial region showing epibranchial spine (e) Petrolisthes rufescens, male, CL: $11.2 \mathrm{~mm}, \mathrm{CW}: 9.0 \mathrm{~mm}$ (e1) same, carapace branchial region 


\section{Colour}

In fresh specimens, entirely grey.

\section{Habitat}

Found beneath the dead coral rock in lower intertidal zone.

\section{Distribution}

Southern India, Mergui Archipelago, Australia, South China Sea, Korea and Japan (Komai, 2000), Goa (Hiller et al. 2010). Presently, it is reported from the Gulf of Kutch, Gujarat (Table 1).

\section{Remarks}

This species was previously reported as Porcellana ornata by Gravely (1927) from Krusadai Island in the Gulf of Mannar and by Sankolli (1968) from Ratnagiri coast of India. Recently, Hiller et al. (2010) reported E. ornatus from Goa. This is the first report of E. ornatus from Gujarat coastline.

\section{Genus Pachycheles Stimpson, 1858}

2. Pachycheles tomentosus Henderson, 1893 (Fig. 2b)

\section{Synonymy}

Pachycheles tomentosus Henderson, 1893.

\section{Material examined}

1ठ, CL: $8.2 \mathrm{~mm}, \mathrm{CW}: 7.5 \mathrm{~mm}$.

\section{Description}

Carapace as long as broad; front depressed, covered with setae. Chelipeds unequal in shape but similar in armature; merus with rounded projection on anterodistal edge; carpus convex, densely hairy, and with three longitudinal rows of four or five tubercles on dorsal surface, anterior margin serrated with three blunt teeth; palm flattened on dorsal surface, tuberculate and densely tomentose anteriorly, setae arranged in short tufts; fingers with wide gap when closed, tip of movable finger bent underside tip of immovable finger. Ambulatory legs covered with feathery setae; merus and carpus unarmed; propodus with two small spines at distal end of posterior margin; dactylus with three small spines on posterior margin.

\section{Colour}

In fresh specimen, entirely light brown.

\section{Habitat}

Mostly seen in lower intertidal zone; preferred rocky substratum with large boulders and small crevices.

\section{Distribution}

Western Indian Ocean, Persian Gulf, Gulf of Oman and Pakistan (Siddiqui and Kazmi 2003; Kazmi and Siddiqui, 2006; Naderloo and Türkay, 2012; Naderloo et al. 2013). Presently it is reported from Veraval coast, Gujarat, India.

\section{Remarks}

This species was originally described by Henderson (1893) from Karachi, Pakistan, and then has been recorded from different regions in Indian Ocean. We firstly report Pachycheles tomentosus from Gujarat coast.

\section{Genus Petrolisthes Stimpson, 1858}

3. Petrolisthes boscii (Audouin, 1826) (Fig. 2c)

\section{Synonymy}

? Porcellana rugosa White, 1847; Porcellana boscii Audouin, 1826; Petrolisthes rugosus Miers, 1884; Petrolisthes amakusensis Miyake and Nakasone, 1966.

\section{Material examined}

19, CL: $9.0 \mathrm{~mm}, \mathrm{CW}: 8.3 \mathrm{~mm}$; 2仓, (1) CL: $12.0 \mathrm{~mm}$, CW: $11.9 \mathrm{~mm}$; (2) CL: $7.1 \mathrm{~mm}, \mathrm{CW}: 6.9 \mathrm{~mm}$.

\section{Description}

Carapace slightly longer than broad, entirely covered with transverse striae, front slightly depressed, triangular with distinct median groove on dorsal surface; small acute epibranchial spine present at anterior end of cervical groove. Chelipeds almost equal in size and armature, entirely covered with striations; merus with rounded projection at anterodistal edge; carpus with four sharply tipped, broad teeth on anterior margin and with two sharp spines at posterodistal end. Ambulatory legs covered with feathery setae; merus with one spine at posterodistal end in second and third pereopods while unarmed in fourth pereopod carpus of second pereopod with one spine at anterodistal end; propodus with two spines on distal end of posterior margin; dactylus with three movable spines on posterior margin.

\section{Colour}

In fresh specimens, generally pinkish red with white striation. This white striation is also observed in preserved specimens.

\section{Habitat}

Mostly found in upper intertidal zone; sandy-muddy substratum or under large steady boulders. 


\section{Distribution}

Indian Ocean, from Red Sea to Mergui Archipelago; Western Pacific from Japan to Malay Archipelago and Australia (Komai, 2000). Presently, reported from different coastal areas of Gujarat, India (Table 1).

\section{Petrolisthes lamarckii (Leach, 1820) (Fig. 2d)}

\section{Synonymy}

Pisidia lamarckii Leach, 1820; Porcellana bellis Heller, 1865; Porcellana dentata H. Milne Edwards, 1837; Porcellana pulchripes White, 1847; Porcellana speciosa Dana, 1852.

\section{Material examined}

1ㅇ, CL: $18.3 \mathrm{~mm}, \mathrm{CW}: 15.2 \mathrm{~mm}$; 10, CL: $14.2 \mathrm{~mm}, \mathrm{CW}:$ $13.0 \mathrm{~mm}$.

\section{Description}

Carapace as long as broad; front slightly depressed, triangular, with distinct groove on dorsal midline; small sharp epibranchial spine present at anterior end of cervical groove (Fig. 2d1). Chelipeds nearly identical in shape and armature, with weak striation on dorsal surface; merus with rounded projection at anterodistal edge; carpus serrated with four to five unequal-sized teeth on dorso-anterior margin; posterior margin terminating in bifid spine; palm broad, anterior margin convex, unarmed. Ambulatory legs covered with feathery setae; merus with one spine at posterodistal end in second and third pereopods, unarmed in fourth pereopods carpus with one spine at anterodistal end in second pereopod but unarmed in third and fourth pereopods; propodus with two spines on distal end of posterior margin; dactylus with three or four movable spines on posterior margin.

\section{Colour}

In fresh specimens, generally light brown, carapace with red patches and two orange spots on branchial region, ambulatory legs with distinct white bands on propodi.

\section{Habitat}

Mostly found in upper intertidal zone; sandy-muddy substratum with small pebbles or under large steady boulders.

\section{Distribution}

Indo-West Pacific, west to eastern African coast (Osawa and Chan 2010), In India, Goa (Hiller et al. 2010), Saurashtra coast (Trivedi and Vachhrajani 2013) and Gulf of Kutch (Beleem et al. 2014). Presently, reported from different coastal areas of Gujarat, India (Table 1).

\section{Remarks}

This species is similar to $P$. rufescens, but immediately distinguished by having an epibranchial spine at the anterior end of the cervical groove (Kropp, 1984; Osawa, 2007; Hiller et al. 2010). Numbers of teeth on the anterior margin of the cheliped carpus are known to vary in P. lamarckii (e.g., Osawa, 2007 and Poupin et al. 2013), while Osawa and Chan (2010) described two morphologically distinct forms based on the armature of the pereopods and shape of rostrum. In view of that our specimens are resemble to the second form of $P$. lamarckii shown by Osawa and Chan (2010: Fig. 113DF). Taxonomy of this species also remains complicated (Osawa, 2007; Osawa and Chan, 2010; Poupin et al. 2013).

\section{Petrolisthes rufescens (Heller, 1861) (Fig. 2e)}

\section{Synonymy}

Porcellana rufescens Heller, 1861.

\section{Material examined}

2ㅇ, (1) CL: $7.7 \mathrm{~mm}, \mathrm{CW}: 6.4 \mathrm{~mm}$; (2) CL: $11.2 \mathrm{~mm}$, CW: $9.0 \mathrm{~mm}$; 20, (1) CL: $7.3 \mathrm{~mm} \mathrm{CW:} 6.2 \mathrm{~mm}$; (2) CL: $6.3 \mathrm{~mm}, \mathrm{CW}: 5.8 \mathrm{~mm}$.

\section{Description}

Carapace longer than broad; front slightly depressed; no spine at anterior end of the cervical groove (Fig. 2e1). Chelipeds nearly identical in size and armature; merus with rounded projection at anterodistal edge; carpus serrated with three blunt teeth on dorso-anterior margin and small sharp spine at posterodistal end. Ambulatory legs covered with feathery setae; meri and carpi without spines; propodus with four or five spines on posterior margin; dactylus with three movable spine on posterior margin.

\section{Colour}

Body entirely dark green or light brown with red patches, chela red with black tips.

\section{Habitat}

Lower intertidal zone; beneath rocks, preferred porous rocks.

\section{Distribution}

Zanzibar, Mozambique, Red Sea, Persian Gulf (Haig, 1964), Iran (Naderloo and Türkay, 2012), Pakistan and Nicobar Island (Apel, 2001). In India, this species has been recorded only from the Gulf of Kutch by Haig (1964) and Mustaquim (1972), but they gave no descriptions. Presently, reported from Gulf of Kutch, India (Table 1). 


\section{Remarks}

Petrolisthes rufescens closely resembles $P$. borradailei Kropp, 1984, but differs in having only a smooth distal projection instead of two sharp spines on the posterior margin of the cheliped carpus (Kropp, 1984). Petrolisthes rufescens is also allied to P. tuerkayi Naderloo and Apel, 2014 in the absence of epibranchial spine, but distinguished by having only a distal spine instead of three or four spines on the posterior margin of the cheliped carpus (Naderloo and Apel, 2014).

\author{
Abbreviations \\ $\mathrm{CL}$, The sizes of specimens are indicated as carapace length; $\mathrm{CW}$, carapace \\ width, in $\mathrm{mm}$
}

\section{Acknowledgement}

We are very much thankful to the head, of the Department of Life Sciences, Maharaja Krishnakumarsinhji (Bhavnagar University, Bhavnagar). Authors are also grateful to Dr R S Kundu, (Department of Biosciences, Saurashtra University, Rajkot), for directing research pathway. First author (IB) is thankful to the University Grant Commission for providing financial support as Maulana Azad National Fellowship (MANF scheme). Second Author (PP) is thankful to the University Grant Commission for providing financial support as Basic Science Research fellowship. Authors are thankful to Dr. Masayuki Osawa (Shimane University, Japan), Drs. Alireza Sari and Reza Naderloo (University of Tehran, Iran) for their help and suggestions in identification of porcelain crabs.

\section{Authors' contributions}

IB did the taxonomy of porcelain crabs, IB and PP wrote the manuscript, and BG scrutinized and finalized the manuscript. All authors read and approved the final manuscript.

\section{Authors' information}

IB: M.Sc. Marine Science, Ph.D. Research Scholar (Zoology) at Department of Life Science, MK Bhavnagar University, Bhavnagar, India. PP: M.Sc. Zoology, M.Phil. Zoology, Ph.D. Zoology (Marine Ecology). Teaching Assistant at Department of Marine Science, MK Bhavnagar University, Bhavnagar, India. BG: M.Sc. Zoology, Ph.D. Zoology (Marine Ecology), Assistant Professor at Department of Life Science, MK Bhavnagar University, Bhavnagar, India.

\section{Competing interests}

The authors declare that they have no competing interests.

\section{Author details}

'Department of Life Sciences, Maharaja Krishnakumarsinhii Bhavnagar University, Bhavnagar 364002, India. ²Department of Biosciences, Saurashtra University, Rajkot 360005, India.

Received: 4 May 2016 Accepted: 6 June 2016

Published online: 22 July 2016

\section{References}

Ahmed M, Mustaquim J. Population structure of four species of porcellanid crabs (Decapoda: Anomura) occurring on the coast of Karachi. Mar Biol. 1974;26:173-82.

Apel M. Taxonomie und Zoogeographie der Brachyura, Paguridea und Porcellanidae (Crustacea: Decapoda) des Persisch-Arabischen Golfes. Frankfurt: Unpublished doctoral thesis, Johann Wolfgang GoetheUniversität; 2001. p. 268.

Beleem IB, Yogesh Kumar JS, Satyanarayana C, Venkataraman K, Kamboj RD. Distribution of Marine Crabs from the Marine National Park, Gulf of Kutch Sch Acad J Biosci. 2014;2(7):419-27.

Dolorosa RG, Werding B. A new mangrove-inhabiting porcelain crab of the genus Enosteoides (Crustacea: Decapoda: Anomura) from Puerto Princesa Bay, Palawan, the Philippines. B Mar Sci. 2014;90(3):865-72.
Gravely FH. The littoral fauna of Krusudai Island in the Gulf of Mannar, orders Decapoda (except Paguridae) and Stomatopoda. Bull Madras Gov Mus. 1927;1:135-55. pls. 19-26.

Haig J. Porcellanid Crabs from the Indo-West Pacific, Part I, papers from Dr. Th. Mortensen's Pacific Expedition 1914-1916. 81. Videnskabelige Meddelelser Dansk Naturhistrisk Forening i Kjøbenhavn. 1964;126:355-86.

Haig J. Porcellanid crabs from the Indo-West Pacific, Part II, Steenstrupia. Zool Mus Univ Copenhagen. 1981;7(12):269-91.

Heller, C. Crustaceen. In: Reise der oesterreichischen Fregatte "Novarra" um die Erde, in den Jahren 1857, 1858, 1859, unter den Befehlen des Commodore B. von Wullerstorf- Ubair. Zoologischer Theil. 1865;2(3), Vienna. 280 pp.

Heller C. Neue Crustaceen, gesammelt wahrend der Weltumseglung der k. k. Fregatte Novara. Zweiter vorläufi ger Bericht Verhandlungen der KaiserlichKöniglichen Zoologisch-Botanischen Gesellschaft in Wien. 1862;12:519-28.

Henderson JR. A contribution to Indian Carcinology. Trans Linn Soc Lond. 1893;5:325-458. pls. 36-40.

Hiller A, Lazarus JF, Werding B. New records and range extensions for porcellanid crabs in the eastern Pacific (Crustacea: Anomura: Porcellanidae). In: Hendrickx ME, editor. Contributions to the Study of East Pacific Crustaceans 3. Mexico: Anales Del Instituto De Ciencias Del Mar Y Limnologia. UNAM; 2004. p. 127-38.

Hiller A, Kraus H, Almon M, Werding B. Petrolisthes galathinus complex: species boundaries based on color pattern, morphology and molecules, and evolutionary interrelationships between this complex and other Porcellanidae (Crustacea: Dcapoda: Anomura). Mol Phylogenet Evol. 2006:40:547-69.

Hiller A, Harkantra S, Werding B. Porcellanid crabs from Goa, eastern Arabian Sea (Crustacea: Decapoda: Porcellanidae). J Bombay Nat Hist Soc. 2010;107(3):201-12.

Kazmi QB, Siddiqui FA. An illustrated key to the Malacostraca (crustacean) of the Northern Arabian Sea, Part VI: Decapoda, Anomura. Pakistan J Mar Sci. 2006;15(1):11-79.

Komai T. A checklist of Thalassinidea and Anomura (Crustacea: Decapoda) from the South China Sea. Raff Bull Zool. 2000;343-376.

Kropp RK. Three new species of Porcellanidae (Crustacea: Anomura) from the Mariana Islands and a discussion of Borradaile's Petrolisthes lamarckii complex. Micronesica. 1984;19:91-106.

Kumaralingam S, Raghunathan C, Venkataraman K. First record of the commensal porcelain crab, Neopetrolisthes spinatus (Crustacea: Decapoda: Anomura: Porcellanidae) from India. Mar Biodivers Rec. 2015;8:e90. 201, 1-3.

Mustaquim J. Species of porcellanid crabs from Karachi. Pak J Zool. 1972:4(2):153-9.

Naderloo R, Türkay M. Decapod crustaceans of the littoral and shallow sublittoral Iranian coast of the Persian Gulf: Faunistics, Biodiversity and Zoogeography. Zootaxa. 2012;3374:1-67.

Naderloo R, Apel M. A new species of porcelain crab, Petrolisthes tuerkayi n. sp. (Crustacea: Anomura: Porcellanidae), from the Persian Gulf. Zootaxa. 2014;3881:190-4. doi:10.11646/zootaxa.3881.2.7.

Naderloo R, Türkay M, Sari A. Intertidal habitats and decapod (Crustacea) diversity of Qeshm Island, a biodiversity hotspot within the Persian Gulf. Mar Biodiv. 2013; 1-18, doi:10.1007/s12526-013-0174-3

Osawa M. Porcellanidae (Crustacea: Decapoda: Anomura) from New Caledonia and the Loyalty Islands. Zootaxa. 2007;1548:1-50.

Osawa M, Chan TY. Part III Porcellanidae (Porcelain crabs). In: Chan T-Y, editor. Crustacean Fauna of Taiwan: Crab-like Anomurans (Hippoidea, Lithoidoidea and Porcellanidae). Keelung: National Taiwan University; 2010. p. 67-181.

Osawa M, McLaughlin PA. Annotated checklist of anomuran decapod crustaceans of the world (exclusive of the Kiwaioidea and families Chirostylidae and Galatheidae of the Galatheoidea) Part II - Porcellanidae. Raff Bull Zool. 2010;23:109-29.

Osawa M, Uyeno D. A new subtidal species of the genus Petrolisthes Stimpson, 1858 (Crustacea: Decapoda: Porcellanidae) from Okinawa, with an account of species of the genus known from the Ryukyu Islands, southwestern Japan. Zootaxa. 2013;3670(3):329-38.

Poore GCB, Ahyong ST. Porcellanidae Haworth, 1825. Marine decapod Crustacea of Southern Australia: a guide to identification. CSIRO Publishing. 2004; pp. 242-246. ISBN 978-0-643-06906-0.

Poupin J, Bouchard JM, Dinhut V, Cleva R, Dumas J. Anomura (Crustacea Decapoda) from the Mayotte region, Western Indian Ocean. Atoll Res Bull. 2013;593-23:1-73. 
Prakash S, Kumar TTA, Gopi M, Balasubramanian T. First record of four species of Petrolisthes (Crustacea: Decapoda: Anomura: Porcellanidae) from Lakshadweep, India. Mar Biodivers Rec. 2013a;6(e47):1-5.

Prakash S, Thangappan T, Kumar A, Khan SA. Checklist of the Porcellanidae (Crustacea: Decapoda: Anomura) of India. Check List. 2013b;9(6):1514-8.

Sankarankutty C. On the porcellanid crab, Porcellanella triloba White

(Crustacea -Anomura) a commensal on sea pen, with remarks on allied species. J Mar Biol Assoc India. 1961a;3:96-100.

Sankarankutty C. On a new genus of Porcellanidae (Crustacea - Anomura). J Mar Biol Assoc India. 1961b;3:92-5.

Sankarankutty C. On three species of porcellanids (crustacea-anomura) from the Gulf of Mannar. J Mar Biol Assoc India. 1963;5(2):273-9.

Sankolli KN. On the Porcellanidae (Crustacea: Anomura) of Ratnagiri along the west coast of India. In: Proceedings of symposium on Crustacea. Mar. biol. Ass. India: Mandapam camp Part l; 1966. p. 295-313.

Sankolli, KN. On the Porcellanidae (Crustacea: Anomura) of Ratnagiri along the west coast of India. In: Proceedings of the Symposium on Crustacea held at Ernakulam from January 12 to 15, 1965. Part I. Mar. Biol. Ass. India. Symposium Series. 1968;2:295-313.

Siddiqui FA, Kazmi QB. A checklist of marine anomurans (Crustacea: Decapoda) of Pakistan, northern Arabian Sea. Mem Mus Vic. 2003;60(1):87-9.

Southwell T. Anomura. Ceylon Pearl Oyster Fisheries. 1906;5:211-24.

Southwell T. Report on the Anomura collected by Mr. James Hornell at Okha Mandal in Kattiawar in 1905-6. In: Hornell J, editor. Report to the Government of Baroda on the marine ecology of Okha Mandal in Kattiawar. Part I. London. 1909. p. 105-123

Trivedi JN, Vachhrajani KD. First record of two porcellanid crabs from Gujarat state, India (Crustacea: Decapoda: Porcellanidae). J Mar Biol Assoc India. 2013;55:55-8

Wasson K, Lyon BE, Knope M. Hair-trigger autotomy in porcelain crabs is a highly effective escape strategy. Behav Ecol. 2002;13:481-6.

Werding B. Kommensalische Porzellaniden aus der Karibik (Decapoda, Anomura). Crustaceana. 1983:45:1-14

Werding B, Hiller A. Description of a new species of Petrolisthes from the western Pacific (Decapoda, Anomura, Porcellanidae). Crustaceana. 2004;77:257-64

Werding B, Hiller A. The Porcellanidae (Crustacea: Decapoda: Anomura) of the Red Sea with description of a new species of Petrolisthes. Zootaxa. 2007;1460:1-24.

\section{Submit your next manuscript to BioMed Central and we will help you at every step:}

- We accept pre-submission inquiries

- Our selector tool helps you to find the most relevant journal

- We provide round the clock customer support

- Convenient online submission

- Thorough peer review

- Inclusion in PubMed and all major indexing services

- Maximum visibility for your research

Submit your manuscript at www.biomedcentral.com/submit

C Biomed Central 